\title{
First record of Haemaphysalis concinna (Acari: Ixodidae) in Lower Silesia, SW Poland
}

\author{
Dorota Kiewra ${ }^{1} \cdot$ Aleksandra Czułowska $^{1}$ - Dagmara Dyczko ${ }^{1} \cdot$ Remigiusz Zieliński $^{1}$. \\ Kinga Plewa-Tutaj ${ }^{1}$ (i)
}

Received: 23 October 2018 / Accepted: 4 February 2019 / Published online: 13 February 2019

(c) The Author(s) 2019

\begin{abstract}
Haemaphysalis concinna Koch is one of 19 species of the genus Haemaphysalis which has been reported in the Palearctic region. In Europe, the presence of $H$. concinna ticks has been reported in numerous countries. In Poland, to date, the precise occurrence of $H$. concinna was known only from one site in the north-western region. This paper shows that $H$. concinna ticks can be considered a typical example of the tick fauna occurring in Lower Silesia, SW Poland. Tick monitoring was conducted using a standard flagging method in 24 sites in the various forest types of Lower Silesia. Among 1622 host-seeking ticks collected, $H$. concinna accounted for $2.7 \%$. From the collected $H$. concinna there were: 25 (58.1\%) larvae, 15 (34.9\%) nymphs, 1 (2.3\%) female, and 2 (4.7\%) males. The presence of $H$. concinna was confirmed in 6 out of 24 tested sites in fresh mixed broadleaf forests, fresh mixed coniferous forests and in pastures.
\end{abstract}

Keywords Haemaphysalis concinna $\cdot$ Poland $\cdot$ Geographical distribution · Ticks

\section{Introduction}

Haemaphysalis concinna Koch, known as a Relict tick, is one of 19 species of the genus Haemaphysalis reported in the Palearctic region (Estrada-Peña et al. 2017). Haemaphysalis concinna is a non-nidicolous tick with a three-host development cycle which is usually completed within 3 years. The hosts of $H$. concinna are both wild and domestic animals, including small and medium-sized mammals, birds, and reptiles (Nowak-Chmura and Siuda 2012; Hornok et al. 2016; Meng et al. 2016; Rubel et al. 2018). Humans can be attacked by nymphs and adults (Nowak-Chmura and Siuda 2012). Haemaphysalis concinna can be found in different habitats, most often in well-lit deciduous and mixed forests with bushy undergrowth, forest clearings, lake shores, and river valleys, as well as forest steppes and wet steppe habitats (Nosek 1971; Siuda 1993; Nowak-Chmura and Siuda 2012; Rubel et al. 2018). The medical and veterinary significance of $H$. concinna is related

Kinga Plewa-Tutaj

kinga.plewa-tutaj@uwr.edu.pl

1 Department of Microbial Ecology and Environmental Protection, Institute of Genetics and Microbiology, University of Wrocław, Przybyszewskiego str. 63/77, 51-148 Wrocław, Poland 
to its proven vector role in the tick-borne encephalitis (TBE) virus and tularemia-causing bacteria Francisella tularensis (Rubel et al. 2018). Infection with other pathogens has also been detected, including severe fever with the thrombocytopenia syndrome virus (Meng et al. 2015), Rickettsia spp. (Igolkina et al. 2018) and Babesia spp. (Hamšíková et al. 2016; Rybářová et al. 2017).

Haemaphysalis concinna occurs in the temperate climate zone of a large part of Eurasia, between $28^{\circ}$ and $64^{\circ}$ north latitude, from Spain in the west to Japan and Kamchatka, Russia, in the east (Rubel et al. 2018). However, the range of its occurrence is discontinuous (Siuda 1993). In Europe, H. concinna has been reported in France, Germany, Belarus, Italy, Austria, the Czech Republic, Slovakia, Hungary, Romania, Moldova, Ukraine, Bulgaria, Croatia, Serbia, Spain, Bosnia-Herzegovina, Greece, and Poland. In Poland, according to Siuda (1993), the first occurrence of $H$. concinna dates from 1911; however, the records do not contain a precise location of the collection. The only well-known site of H. concinna in Poland, described in the 1950s, is located in the north-western part of the country in the West Pomeranian voivodship (in the locality of Troszyn), where one female was collected from the vegetation (Siuda 1993).

This paper shows, for the first time, that $H$. concinna ticks can be considered a typical example of the tick fauna occurring in Lower Silesia, SW Poland.

\section{Materials and methods}

Host-seeking ticks were collected from March to September 2018 using a standard flagging method in 24 sites located in forested areas of Lower Silesia (Fig. 2). Each single site was flagged for at least $60 \mathrm{~min}$, in daytime between 9 a.m. and 3 p.m., avoiding rainy and windy days. In two sites (10 and 11) $1 \mathrm{~h}$ flagging was repeated 6x, in 9 sites (1-9) it was repeated $3 \mathrm{x}$, and only once in the remaining sites.

The dominant forest habitat type in particular study areas was determined on the basis of the Forest Data Bank (https://www.bdl.lasy.gov.pl/portal/mapy). The study included areas located in different forest types. The predominant forest type of the study areas is mixed broadleaf and coniferous forest. Some sites are also located in fresh coniferous forest, moist broadleaf forest, riparian forest, and pastures. In the forests where the research was carried out, the dominant tree species were pine (Pinus sylvestris), birch (Betula pendula), beech (Fagus sylvatica), common oak (Quercus robur), spruce (Picea abies) and larch (Larix decidua).

All collected ticks were identified to a species level according to the Ixodida identification key (Siuda 1993; Nowak-Chmura 2013; Estrada-Peña et al. 2017). To confirm the species identification of nymphs and larvae initially classified as Haemaphysalis sp., additional microscopic preparations were made from randomly selected specimens. The site was considered as positive for $H$. concinna occurrence when at least one specimen was found.

\section{Results}

A total of 1622 host-seeking ticks were collected, including 1546 Ixodes ricinus (95.3\%), 33 Dermacentor reticulatus (2.0\%), and 43 Haemaphysalis concinna (2.7\%). From the collected $H$. concinna, 25 (58.1\%) were larvae, 15 (34.9\%) were nymphs, 1 (2.3\%) was 
Fig. 1 Morphology of gnathosoma of Haemaphysalis concinna larvae identified in Lower Silesia
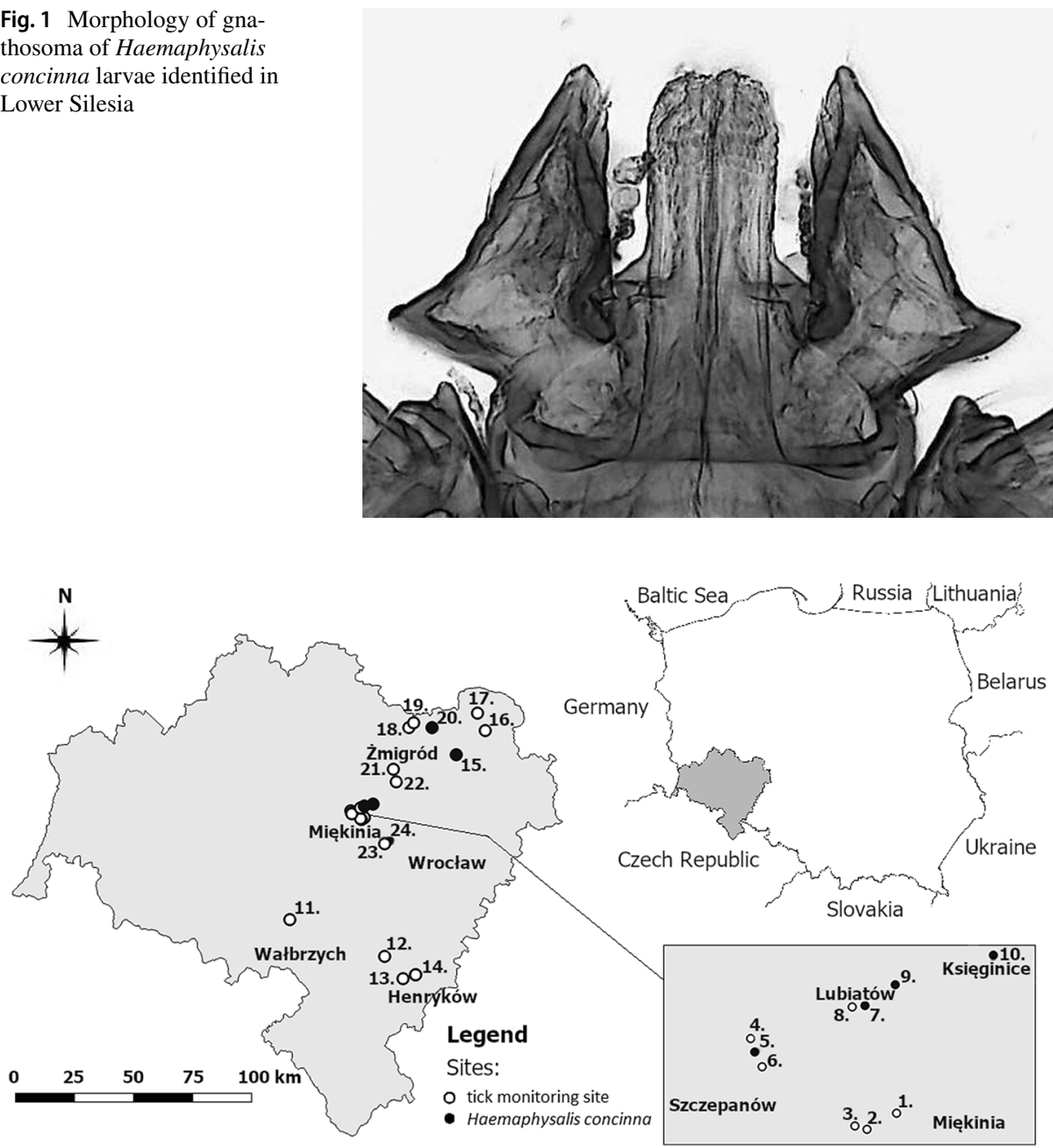

Fig. 2 Tick monitoring sites and Haemaphysalis concinna habitats located in Lower Silesia

female, and $2(4.7 \%)$ were males (Fig. 1). The presence of $H$. concinna was confirmed in 6 out of 24 tested sites in fresh mixed broadleaf forest, fresh mixed coniferous forest and pasture land (Fig. 2; Table 1). All specimens of this species were collected from May to August, of which: females and males were collected only in May, nymphs from May to August, and larvae from June to August.

\section{Discussion}

In Europe, the presence of $H$. concinna has been reported from many countries. In Poland, to date, the precise occurrence of $H$. concinna was known only from one site in the northwestern region (Siuda 1993; Nowak-Chmura and Siuda 2012). This study shows, for the 


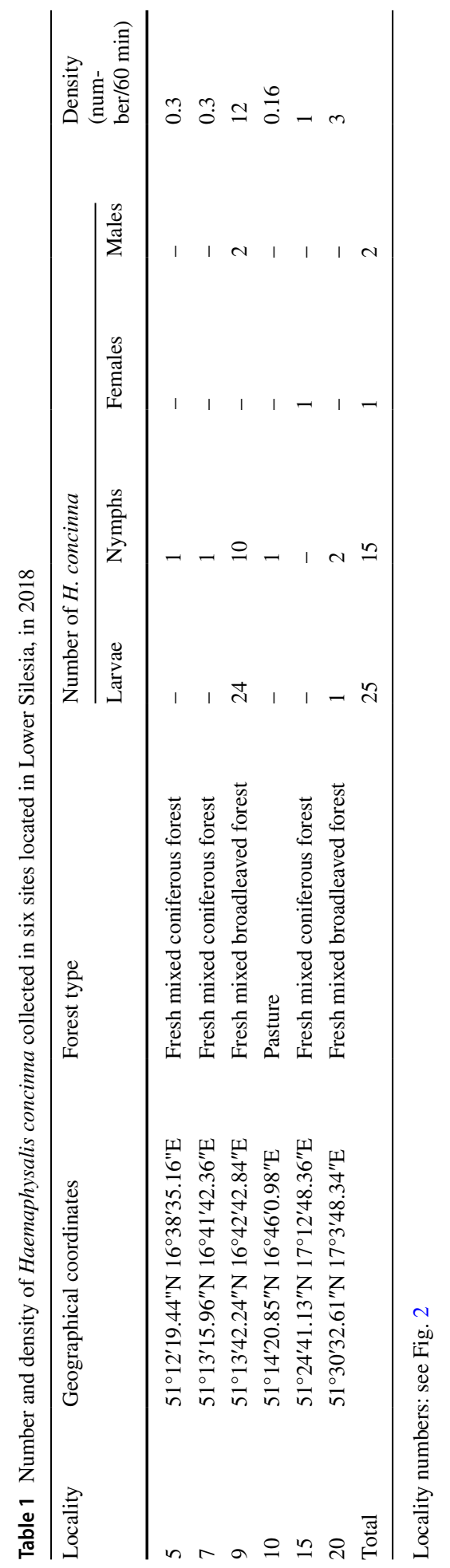


first time, that $H$. concinna also occurs in the south-western part of Poland. The closest previously-known location of $H$. concinna to our site is in Germany. Among others, Rubel et al. (2014) found ticks at a site in the eastern part of Germany (Brandenburg), near the border with Poland, which can be seen on a geo-referenced map plotting over 2000 tick locations. This position is located about $190 \mathrm{~km}$ from the newly-recorded Lower Silesian location. The sites of $H$. concinna reported from the Czech Republic are located in Moravia, south of Brno (Rybářová et al. 2017), at a distance of about $245 \mathrm{~km}$ from our location.

Among 1622 host-seeking ticks we collected using flagging, $H$. concinna accounted for 2.7\%. The most abundant tick species found was I. ricinus $(95.3 \%) .2 .0 \%$ of the ticks were $D$. reticulatus. In other European studies, the share of $H$. concinna among ticks collected from vegetation varies but is always smaller than the share of I. ricinus. In Slovakia, for example $H$. concinna comprised $1.3 \%$ of the tick collections while I. ricinus was $98.6 \%$ (Kazimírová et al. 2016), and in Hungary H. concinna was $17.8 \%$ and I. ricinus $78.6 \%$ (Hornok et al. 2014).

In the environment, all free-living stages of $H$. concinna quest for hosts climbing up vegetation. In our study, carried out using the flagging method, both adult ticks (female and males) and immature stages (larvae and nymphs) of $H$. concinna were present. The presence of all developmental stages of $H$. concinna in the tick population collected from vegetation is also recorded in other countries. In Slovakia, for example, among $82 \mathrm{H}$. concinna collected using dragging, larvae were 27\%, nymphs 48\%, and adults 25\% (Kazimírová et al. 2016); in Hungary, among 437 ticks, the instances of larvae, nymphs and adults were 91, 5, and 4\% respectively (Hornok et al. 2014); and in China, among a very large collection of almost 3000 questing specimens, larvae were $30 \%$, nymphs $36 \%$, and adults $34 \%$ (Meng et al. 2016).

In Central Europe, adult $H$. concinna ticks are chiefly active from May to July, nymphs from mid-April to mid-October, and larvae from late May to mid-October (Rubel et al. 2018). In our study, carried out from March to September, all specimens of H. concinna were collected from May to August, of which: adults were collected only in May, nymphs from May to August, and larvae from June to August. However, further systematic studies are necessary to precisely estimate the seasonal activity of $H$. concinna in SW Poland.

In our study, $H$. concinna was collected in fresh mixed broadleaf forest, fresh mixed coniferous forest and pasture land, and the habitat of $H$. concinna collected in NW Poland (the West Pomeranian voivodeship, Troszyn) was fresh mixed broadleaf forest near a lake (Siuda 1993). In temperate Eurasia, H. concinna is widely distributed both in wild, suburban and urban environments, including deciduous and mixed forests, relatively humid places, overgrown lake shores, and river basins (Nosek 1971; Hornok et al. 2014; Kazimírová et al. 2016; Rybářová et al. 2017). Thus, the habitats where H. concina was found in Poland do not differ from the typical habitats recorded in other European countries.

Finding the host-seeking $H$. concinna ticks in 6 localities in Lower Silesia shows that this tick species can be considered as a typical element of the tick fauna in SW Poland. It also indicates the necessity for further systematic environmental monitoring of its occurrence, as well as the need to take $H$. concinna into account during research into the circulation of tick-borne pathogens in SW Poland.

Acknowledgements The authors would like to acknowledge MSc Magdalena Turzańska from the Department of Plant Developmental Biology, Institute of Experimental Biology, University of Wrocław, for taking photos. 
Open Access This article is distributed under the terms of the Creative Commons Attribution 4.0 International License (http://creativecommons.org/licenses/by/4.0/), which permits unrestricted use, distribution, and reproduction in any medium, provided you give appropriate credit to the original author(s) and the source, provide a link to the Creative Commons license, and indicate if changes were made.

\section{References}

Estrada-Peña A, Mihalca AD, Petney TN (eds) (2017) Ticks of Europe and North Africa. A guide to species identification. Springer, New York

Hamšíková Z, Kazimírová M, Haruštiaková D, Mahríková L, Slovák M, Berthová L, Kocianová E, Schnittger L (2016) Babesia spp. in ticks and wildlife in different habitat types of Slovakia. Parasit Vectors 9:292. https://doi.org/10.1186/s13071-016-1560-z

Hornok S, Meli ML, Gönczi E, Halász E, Takács N, Farkas R, Hofmann-Lehmann R (2014) Occurrence of ticks and prevalence of Anaplasma phagocytophilum and Borrelia burgdorferi s.l. in three types of urban biotopes: forests, parks and cemeteries. Ticks Tick Borne Dis 5(6):785-789. https://doi. org/10.1016/j.ttbdis.2014.05.010

Hornok S, Flaisz B, Takács N, Kontschán J, Csörgő T, Csipak Á, Jaksa BR, Kováts D (2016) Bird ticks in Hungary reflect western, southern, eastern flyway connections and two genetic lineages of Ixodes frontalis and Haemaphysalis concinna. Parasit Vectors 9:101. https://doi.org/10.1186/s13071-016-1365-0

Igolkina Y, Rar V, Vysochina N, Ivanov L, Tikunov A, Pukhovskaya N, Epikhina T, Golovljova I, Tikunova N (2018) Genetic variability of Rickettsia spp in Dermacentor and Haemaphysalis ticks from the Russian Far East. Ticks Tick Borne Dis. https://doi.org/10.1016/j.ttbdis.2018.07.015

Kazimírová M, Hamšíková Z, Kocianová E, Marini G, Mojšová M, Mahríková L, Berthová L, Slovák M, Rosá R (2016) Relative density of host-seeking ticks in different habitat types of south-western Slovakia. Parasit Vectors 9:101. https://doi.org/10.1186/s13071-016-1365-0

Meng K, Sun W, Cheng Z, Guo H, Liu J, Chai T (2015) First detection of severe fever with thrombocytopenia syndrome virus in the tick species Haemaphysalis concinna in Shandong Province, China. Parasitol Res 114:4703-4707. https://doi.org/10.1007/s00436-015-4718-2

Meng H, Xu S, Yu Z, Li N, Wang R, Gao X, Yang X, Liu J (2016) Abundance and seasonal activity of Haemaphysalis concinna (Acari: Ixodidae) at the border between China and Russia in Northern Inner Mongolia, China. Parasit Vectors 9:1. https://doi.org/10.1186/s13071-015-1291-6

Nosek J (1971) The ecology, bionomics and behavior of Haemaphysalis (Haemaphysalis) concinna tick. Z Parasitenk 36:233-241

Nowak-Chmura M (2013) Fauna kleszczy (Ixodida) Europy Środkowej. Wydawnictwo Naukowe Uniwersytetu Pedagogicznego, Kraków

Nowak-Chmura M, Siuda K (2012) Ticks of Poland. Review of contemporary issues and latest research. Ann Parasitol 58:125-155

Rubel F, Brugger K, Monazahian M, Habedank B, Dautel H, Leverenz S, Kahl O (2014) The first German map of georeferenced ixodid tick locations. Parasit Vectors 7:477. https://doi.org/10.1186/s1307 1-014-0477-7

Rubel F, Brugger K, Walter M, Vogelgesang JR, Didyk YM, Fu S, Kahl O (2018) Geographical distribution, climate adaptation and vector competence of the Eurasian hard tick Haemaphysalis concinna. Ticks Tick Borne Dis 9:1080-1089. https://doi.org/10.1016/j.ttbdis.2018.04.002

Rybářová M, Honsová M, Papoušek I, Široký P (2017) Variability of species of Babesia Starcovici, 1893 in three sympatric ticks (Ixodes ricinus, Dermacentor reticulatus and Haemaphysalis concinna) at the edge of Pannonia in the Czech Republic and Slovakia. Folia Parasitol 64:028. https://doi.org/10.14411 /fp. 2017.028

Siuda K (1993) Kleszcze Polski. Acari (Ixodida). Część II. Systematyka i rozmieszczenie. Polskie Towarzystwo Parazytologiczne, Warszawa

Publisher's Note Springer Nature remains neutral with regard to jurisdictional claims in published maps and institutional affiliations. 